\title{
MEREDUKSI PERILAKU PHUBBING MELALUI KONSELING KELOMPOK REALITA BERBASIS ISLAMI
}

\author{
Asroful Kadafi ${ }^{1)}$, Beny Dwi Pratama ${ }^{2)}$, Suharni $^{3)}$, Ibnu Mahmudi ${ }^{4)}$ \\ 1) Bimbingan dan Konseling, Universitas PGRI Madiun, Indonesia \\ Email: asrofulkadafi@unipma.ac.id \\ 2) Bimbingan dan Konseling, Universitas PGRI Madiun, Indonesia \\ Email: benydwipratama@unipma.ac.id \\ 3) Bimbingan dan Konseling, Universitas PGRI Madiun, Indonesia \\ Email: harnibk@unipma.ac.id \\ 4) Bimbingan dan Konseling, Universitas PGRI Madiun, Indonesia \\ Email: mahmudiibnu@unipma.ac.id
}

\begin{abstract}
Abstrak. Perkembangan teknologi yang tidak bisa dipungkiri pada era revolusi Industri 4.0 selain memberikan dampak positif dalam berbagai bidang, juga memberikan dampak negative terutama bagi individu yang tidak bijak dalam menyikapi perkembangan tersebut. Salah satu permasalahan serius adalah permasalahan dibidang social, seperti perilaku phubbing atau lebih fokus pada gadged mereka dari pada lawan bicara. Tujuan dari peneltian ini yaitu untuk menurunkan perilaku phubbing pada Mahasiswa. Sampel dari penelitian ini sebanyak 8 Mahasiswa yang masuk dalam kategori phubbing tinggi. Treatment yang diberikan menggunakan layanan konseling kelompok realita berbasis Islami. Penelitian ini menggunakan metode quasi eksperiment. Analisa dilakukan dengan menggunakan uji Wilcoxon signed rank, yang didapatkan hasil jika konseling kelompok realita berbasis islam efektif untuk menurunkan perilaku phubbing.
\end{abstract}

Kata Kunci: Perilaku phubbing; Konseling Kelompok Realita; Islami

\section{PENDAHULUAN}

Pada tahun 2025 diprediksi lebih dari 5 miliar orang di dunia akan menggunakan ultra-broadband, smartphone yang kaya sensor, jauh melampaui kemampuan iPhone, Android, dan Blackberry yang ada saat ini. Smartphone dapat merekam di mana mereka berada, apa yang mereka lakukan, dan apa yang dapat mereka lihat dan dengar dan dapat menjalankan kegiatan peneltian seperti: survei interaktif, tes, dan eksperimen melalui layar sentuh dan koneksi nirkabel ke layar monitor, headset, biosensor, dan perangkat lainnya [1]. Namun selain dampak postif tersebut peggunakan smartphone yang tidak benar akan berdampak buruk atau dikenal dengan istilah cyberloafing (penggunaan internaet tidak menyelesaikan pekerjaan) [2]. Hasil survei online terhadap 598 peserta di universitas negeri Ankara, Turki menunjukkan bahwa penggunaan smartphone dan cyberloafing mempengaruhi kecanduan smartphone yang berdampak pada lingkungan belajar dan perkembangan individu [2]. Pada penelitian ini focus pada permasalahan social yang diakibatkan dari pemanfaatan smartphone yang salah. Salah satu bentuk nyata dari permasalahan social akibat kecanduan smartphone adalah perilaku phubbing.

Keasyikan dengan smartphone telah mengubah cara berinteraksi seseorang dengan orang lain. Individu yang sudah asyik dengan smartphone cenderung mengabaikan lawan bicara mereka atau sering dikenal dengan istilah phubbing [3]. Dampak berbahaya dari phubbing, dapat membuat individu mengalami rasa pengucilan sosial, yang mengarah pada meningkatnya kebutuhan akan perhatian [3]. Phubbing terjadi ketika orang mengabaikan atau mengabaikan orang lain di sekitar mereka dengan berkonsentrasi pada smartphone mereka [4], [5].

Dimensi dari phubbing dapat dijelaskan dengan contoh kecanduan ponsel, kecanduan SMS, kecanduan media sosial, kecanduan internet, dan kecanduan game [6]. Chotpitayasunondh dan Douglas (2016) mempertegas korelasi moderat antara perilaku phubbing dan kecanduan 
smartphone, kecanduan internet, dan rasa takut ketinggalan [7]. Perilaku ini tentunya jika dibiarkan dapat menimbulkan permasalahan, baik bagi pelaku atau phubber maupun pada korban atau phubbee [8]. Bagi pelaku tanpa disadari oleh dirinya dia mungkin dapat dikucilkan oleh rekan-rekannya dan bagi pubbee bisa membuat dirinya tidak berharga [3], [9]. Untuk itu perlu treatment khusus untuk membantu permasalahan tersebut.

Orang tua sebagai pihak yang sangat inten berinteraksi dengan anak, sangat memungkinkan untuk bisa mengendalikan anak mereka dalam menggunakan smartphone mereka [10]. Namun tentunya tidak semua oranf tua menyadari akan pentingnya peran mereka untuk mampu mengendalikan aktivitas anak mereka. Perlu ada intervensi juga dari pihak pendidik, salah satunya yaitu Konselor sekolah [11]. Konselor sebagai salah satu komponen pendidikan diharpakan sangat berperan untuk bisa memfasilitasi peserta didik untuk bisa menggunakan smartphone mereka secara bijak. Salah satunya dengan pendekatan Agama.

Islam seperti yang tergambarkan dalam sebuah Hadis berikut "Tidak termasuk golongan umatku orang yang tidak menghormati mereka yang lebih tua dan tidak mengasihi mereka yang lebih muda darinya, serta tidak mengetahui hak-hak orang berilmu” (HR. Ahmad) [12] mengambarkan jika ciri seorang Muslim adalah menghargai orang lain. Hadis ini diperkuat dengan Q.S Al Hujurat ayat 10 yang artinya "... (perbaikilah hubungan) antara kedua saudaramu itu dan takutlah terhadap Allah, supaya kamu mendapatrahmat" (QS. Al Hujurat: 10) [13] ayat ini secara tegas menyatakan jika membangun sebuah hungan baik sangat dianjurkan. Dari kajian ini, tentunya perilaku phubbing merupakan perilaku yang bertentangan dengan nilai Islam. Untuk itu dalam upaya mereduksi perilaku phubbing sangat penting untuk mengintegrasikan nilai Islam.

Selain penanaman nilai Islam, tentunya juga perlu adanya layanan yang spesifik untuk membantu permasalahan konseling dalam hal ini adalah Phubber. Dalam penelitian ini peneliti menggunakan layanan konseling kelompok realita untuk menanamkan nilai Islam agar individu menjadi lebih bertanggung jawab dalam menggunakan smartphone dan lebih menghargai orang lain. Konseling kelompok sendiri sebagai media layanan konseling dengan memanfaatkan dinamika kelompok dan sangat cocok untuk memnfasilitasi tumbuhnya nilai-nilai social [14] dan

Pendekatan Realita diharapkan mampu menumbuhkan rasa tanggungjawab social pada individu [14], [15]. Dan pada penelitian sebelumnya peneliti juga telah membuktikan keefektifan internalisasi nilai Islam dalam membantu permasalahan Konseli [16]-[18]. Dari kajian itu, menjadikan dasar peneliti memadukan layanan konseling kelompok Realita berbasis Islam untuk menurunkan perilaku phubbing.

\section{METODE}

Penelitian ini menggunakan pendekatan eksperimen tepatnya quasi experimental design dengan One Group Pretest-Posttest Design. Desain ini digunakan untuk melihat ketapatan treatment, melalui perbandingan perbedaaan antara sebelum dan sesudah mendapat treatment [19]. Treatmen pada penelitian ini dilaksankan sebanyak 4 kali uji coba menggunakan layanan konseling kelompok Realita berbasis Islam. Dengan melalui 4 tahapan konseling Kelompok pada tiap pertemuan, yaitu tahap: pembentukan, transisi, kegiatan dan terminasi [14].

Sampel pada penelitian ini sebanyak 8 Mahasiswa Bimbingan dan Konseling yang masuk memiliki perilaku phubbing tinggi diambil secara purposive sampling. Sampel tentunya telah memenuhi persyaratan, antara lain: beraga Islam dan masuk dalam kategori berperilaku phubbing tinggi. Dalam pengambilan data, peneliti menggunakan instrument adaptasi dari Varoth Chotpitayasunondh, Karen M. Douglas yang telah dialih bahasakan oleh ahli atau tepatnya menggunakan intrumen Generic Scale of Phubbing dengan 7 interval mulai $(1=$ Tidak pernah, $2=$ Jarang, $3=$ Pernah, $4=$ kadang-kadang, $5=$ Sering, $6=$ Biasanya, $7=$ Selalu; [8] Dan untuk analisa data, digunakan uji Wilcoxon Signed Ranks Test yang mengacu pada tidak dipenuhinya uji statistic parametrik.

\section{HASIL DAN PEMBAHASAN}

Hasil analisa secara deskriptif dapat diketahui jika nilai rata-rata hasil skor pretes perilaku phubbing sebelum dilakukan treatmen sebesar 92,12 dan setelah dilakukan tratmen menggunakan layanan konseling kelompok realita berbasis Islami nilai rata-rata turun sebesar 33,88 atau turun sebesar 58,24. Rincian perolehan data disajikan pada tabel 1 .

Tabel 1. Descriptive Statistics

\begin{tabular}{lccccc}
\hline & $N$ & Mean & Std. Dev & Min & Max \\
\hline $\begin{array}{l}\text { Pretest Perilaku } \\
\text { Phubbing }\end{array}$ & 8 & 92.12 & 3.182 & 86 & 96 \\
\hline $\begin{array}{l}\text { Posttest Perilaku } \\
\text { Phubbing }\end{array}$ & 8 & 33.88 & 1.727 & 31 & 36 \\
\hline
\end{tabular}

Mempertegas hasil analisa secara deskriptif, hasil analisis uji Wilcoxon signed rank menunjukan jika z-score menunjukan nilai -2,533 dan p-value sebesar 0,011 atau lebih kecil jika dibandingkan dengan batas kritis penelitian sebesar 0,05. Hasil ini membuktikan jika treatmen dengan konseling kelompok Realita berbasis Islami efektif untuk menurunkan perilaku phubbing pada remaja. Rincian perolehan nilai uji Wilcoxon signed rank ditampilkan pada tabel 2. 
Tabel 2. Hasil Uji Wilcoxon Signed Rank

\begin{tabular}{lc}
\hline & $\begin{array}{r}\text { Posttest Perilaku Phubbing - Pretest } \\
\text { Perilaku Phubbing }\end{array}$ \\
\hline$Z$ & $-2.533^{\mathrm{a}}$ \\
\hline Asymp. Sig. (2-tailed) & .011 \\
\hline
\end{tabular}

Temuan penelitian menujukan jika penggunaan gadged berkaitan IT di Indonesia cukup tinggi. Hal ini berbaikatan karena masyarakat di era 5.0 mencapai konvergensi lanjutan antara ruang maya dan ruang fisik, memungkinkan $A I$ berbasis data besar dan robot untuk melakukan atau mendukung sebagai agen pekerjaan dan penyesuaian yang telah dilakukan manusia hingga saat ini. Ini adalah masyarakat yang berpusat pada setiap orang dan bukan masa depan yang dikendalikan dan dipantau oleh $A I$ dan robot. Mencapai Masyarakat 5.0 dengan atribut-atribut ini akan memungkinkan tidak hanya Jepang tetapi dunia juga untuk mewujudkan pembangunan ekonomi sambil memecahkan masalah sosial utama. Ini juga akan berkontribusi untuk memenuhi Tujuan Pembangunan Berkelanjutan (SDGs) yang didirikan oleh PBB [20].

Salah satu bentuk perkembangan teknologi adalah lahirnya Smartphone yang memungkinkan orang untuk terhubung dengan orang lain dari mana dan kapan saja. Smartphone adalah perangkat yang menawarkan teknologi canggih, fungsinya mirip dengan komputer, mendukung multitasking dan membuatnya mudah untuk tetap terhubung dengan orang lain [21]. Namun, yang berkembang smartphone terkadang justru mengurangi, bukannya melengkapi, interaksi sosial. Bentuk nyata nyata dari perilaku ini adalah perilaku phubbing. Istilah "phubbing" mewakili tindakan menghina seseorang dalam lingkungan sosial dengan berkonsentrasi pada telepon seseorang alihalih berbicara langsung dengan orang tersebut [7]. Ahli lain menyampikan phubbing atau merujuk pada seseorang yang berinteraksi dengan smartphone mereka daripada berkomunikasi dengan lawan bicara dan bisa membuat pelaku phubbing menjadi jengkel jika orang lain melakukan hal yang sama [22].

Karadag et al (2015) mempertegas Phubbing dapat digambarkan sebagai individu yang melihat ponselnya selama percakapan dengan individu lain, fokus dengan ponsel dan melarikan diri dari komunikasi antarpribadi. Phubbing dicirikan dengan aktivitas menampilkan kecanduan ponsel, kecanduan SMS, kecanduan internet, kecanduan media sosial, dan kecanduan game atau dapat dicatat hal penting dari perilaku phubbing adalah ponsel, SMS, media sosial dan kecanduan internet [6].

Salah satu konsekuensi negatif dari "phubbing" adalah menghina seseorang seperti aktivitas lebih mengutamakan melihat handphone di tengah-tengah percakapan kehidupan nyata. Namun disisi lain, pelaku sebenarnya juga merasa kecewa jika lawan bicar juga melakukan aktivitas yang sama [23]. Permasalahan lain yang terjadi seperti Fear-of-missingout (FOMO) mengacu pada perasaan cemas yang timbul dari kesadaran bahwa Anda mungkin kehilangan pengalaman yang bermanfaat yang dimiliki orang lain. FOMO dapat diidentifikasi sebagai sifat intra-pribadi yang mendorong orang untuk tetap mengetahui apa yang dilakukan orang lain, antara lain di platform media sosial. FOMO memperkirakan perilaku phubbing baik secara langsung maupun tidak langsung melalui hubungannya dengan penggunaan media sosial bermasalah (PSMU) [24]. Beberapa permasalahan ini muncul diperkirakan akibat lemahnya penanaman keimanan pada diri individu [25].

Telah jelas dalam Firman Allah SWT Q,S Al Hujurat ayat 10 dijelaskan akan pentingnya saling menghargai sesame muslim. Sehingga jika muslim memiliki keimanan yang baik, tentunya dia tidak akan melakukan phubbing. Individu akan lebih mementingkan silaturahmi atau lawan bicaranya dibandingkan dengan smartphonenya. Penanaman nilai Islam dalam proses konseling juga telah peneliti lakukan sebelumnya. Penelitian pertama mengunakan bimbingan kelompok Islami untuk meningkatkan Aspirasi mahasiswa yang terbukti ekfektif [18]. Penelitian selanjutnya peneliti melakukan uji coba bimbingan kelompok Islami untuk menurunkan prokrastinasi akademik yang juga terbukti efektif [26]. Dalam penelitian ini peneliti mencoba memadukan treatment baru yaitu dengan konseling kelompok realita.

Konseling kelompok realita sendiri juga telah sering digunakan untuk membantu permasalah siswa. Rifda dan Anggralisa (2016) menunjukan jika konseling kelompok realita efektif untuk mengatasi kesulitan komunikasi interpersonal siswa [27]. Maslikan (2018) juga telah memubuktikan jika konseling kelompok realita efektif untuk meningkatkan pemahaman identitas diri siswa [28]. Melihat kefektifan antara konseling kelompok realita dan penanaman nilai Islam dalam membantu permasalahan siswa berdasar beberapa penelitian tersebut mendukung temuan penelitian ini, yaitu konseling kelompok realita berbasis Islam mampu menurunkan tingkat perilaku phubbing pada Mahasiswa.

Intervensi ini tidak terlepas dari tujuan dari penerapan konseling kelompok realita yaitu untuk menanamkan rasa tanggungjawab social individu melalui dinamika kelompok yang ada [14], [15]. Dan intervensi nilai Islam sendiri untuk menekan emosi negative pada individu [17]. Sebelumnya peneliti juga telah mencoba melakukan internalisasi kandungan Al Quran dalam proses konseling realita untuk meningkatkan tanggung jawab akademik siswa.

\section{IV.KESIMPULAN}

Phubbing merupakan perilaku yang seharusnya tidak dilakukan individu pada era disrupsi. Phubbing hanya dapat berdampak negative baik bagi phubber maupun phubbee. Untuk itu perlu ada langkah kongret dari Konselor untk membantu mengatasi permasalahan phubbing. Dari penelitian ini menunjukan jika penanaman nilai Religius dalam proses konseling kelompok Realita dapat menurunkan tingkat phubbing pada Mahasiswa. Namun hasil penelitian ini, baru diujicobakan pada sample yang terbatas, sehingga perlu kehati-hatianya dalam melakukan generalisasi. Disarankan untuk pihak-pihak terkait dapat memanfaatkan 
hasil penelitian ini khususnya untuk membantu permasalahan phubbing.

\section{DAFTAR PUSTAKA}

[1] Miller, G. (2012). The Smartphone Psychology Manifesto. Perspect. Psychol. Sci.

[2] Gökçearslan, S.F.K., Mumcu, T., Haşlaman, \& Çevik, Y. D. (2016). Modelling smartphone addiction: The role of smartphone usage, selfregulation, general self-efficacy and cyberloafing in university students. Computer Human Behavior.

[3] M. E. David and J. A. Roberts. (2017). Phubbed and Alone: Phone Snubbing, Social Exclusion, and Attachment to Social Media. $J$. Assoc. Consum. Res.

[4] V. Chotpitayasunondh and K. M. Douglas. (2018). Measuring phone snubbing behavior: Development and validation of the Generic Scale of Phubbing (GSP) and the Generic Scale of Being Phubbed (GSBP). Comput. Human Behav.

[5] O. Abramova, A. Baumann, H. Krasnova, \& S. Lessmann. 2017). To phub or not to phub: Understanding off-task smartphone usage and its consequences in the academic environment. in Proceedings of the 25th European Conference on Information Systems, ECIS 2017.

[6] E. Karadağ et al. (2015). Determinants of phubbing, which is the sum of many virtual addictions: A structural equation model. J. Behav Addict.

[7] V. Chotpitayasunondh and K. M. Douglas. (2016). How 'phubbing' becomes the norm: The antecedents and consequences of snubbing via smartphone. Comput. Human Behav.

[8] V. Chotpitayasunondh and K. M. Douglas. (2018). Measuring Phone Snubbing Behavior: Development and Validation of the Generic Scale of Phubbing (GSP) and the Generic Scale of Being Phubbed (GSBP). Comput. Human Behav., 88, 5-17.

[9] T. Umari, M. A. Rusandi, and E. Yakub. (2019). Phubbing as a result of the 4th industrial revolution: Is it dangerous?," in Proceeding of the SSO \& $3 r d$ URICES.

[10] X. Fu, J. Liu, R. De Liu, Y. Ding, W. Hong, and S. Jiang. (2020) The impact of parental active mediation on adolescent mobile phone dependency: A moderated mediation model. Comput. Human Behav.

[11] Pratama, B. D., Kadafi, A. \& Suharni, S. (2018). Peran Konselor dalam identifikasi masalah dan kebutuhan siswa underachiever.

[12] A. A. M. bin I. Al-Bukhari. (2011). Ensiklopedia Hadits; Shahih alBukhari 1. Terj. Masyhar dan Muhammad Suhadi. Cet. I, I. Jakarta: Almahira.

[13] Al-Quran. (2015). Departemen Agama RI. Bandung: CV Darus Sunnah.

[14] Corey, G. (2013). Teori dan Praktek Konseling \& Psikoterapi, Terjemahan. Bandung: Refika Aditama.

[15] Myers, D. G. (2012). Introducing social psychology. Soc. Psychol. (Gott)., 1-29.

[16] Kadafi, A. \& Ramli, M. (2017). Integrated qs al mudatsir in the reality group conseling to grow the character of students academic responsibility. Counsel. Jurnal Bimbingan dan Konseling, 7(2), 117125.

[17] Faiz, A., Yandri, H., Kadafi, A., Mulyani, R. R. N., Nofrita, \& Juliawati, D. (2019). Pendekatan Tazkiyatun An-Nafs untuk membantu mengurangi emosi negatif klien. Counsel. Jurnal Bimbingan dan Konseling, 9(1), 65-78.

[18] Kadafi, A. (2017). Efektivitas Bimbingan Kelompok Islami untuk Meningkatkan Aspirasi Karir Mahasiswa, Univ. Ahmad Dahlan, 5(1) 43-48.

[19] Sugiyono. (2016). Metode Penelitian dan Pengembangan (Research and Development $/ R \& D$ ).

[20] C. Office. (2019). "Society 5.0," https://www8.cao.go.jp. [Online]. Available:

https://www8.cao.go.jp/cstp/english/society5_0/index.html.

[Accessed: 26-Jun-2019].

[21] M. Anshari, Y. Alas, G. Hardaker, J. H. Jaidin, M. Smith, \& A. D. Ahad. (2016). Smartphone habit and behavior in Brunei: Personalization, gender, and generation gap. Computer. Human Behavior.
[22] I. M. Hanika. (2015). FENOMENA PHUBBING DI ERA MILENIA (Ketergantungan Seseorang pada Smartphone terhadap Lingkungannya). Jurnal Interaksi.

[23] S. Balta, E. Emirtekin, K. Kircaburun, and M. D. Griffiths, (2018). Neuroticism, Trait Fear of Missing Out, and Phubbing: The Mediating Role of State Fear of Missing Out and Problematic Instagram Use. International Journal of Mental Health and Addiction.

[24] Van Rooij, A. J., Lo Coco, G. L., De Marez, Franchina, V. \& Vanden Abeele, M. (2018). Fear of missing out as a predictor of problematic social media use and phubbing behavior among flemish adolescents. International Journal Environtment Res. Public Health.

[25] Sutoyo, A. (2009). Bimbingan dan Konseling Islami. Semarang: Widya Karya,

[26] Kadafi, A., Ramatus, M.R. \& Desy, R.N.K. (2018). Upaya Menurunkan Prokrastinasi Akademik Mahasiswa melalui Bimbingan Kelompok Islami,. Jurnal EDUKASI, 4(2), 181-193.

[27] Fiah, R. \& Anggralisa, I. (2016). Efekitvitas Layanan Konseling Kelompok dengan Pendekatan Realita untuk Mengatasi Kesulitan Komunikasi Interpersonal Peserta Didik Kelas X MAN Krui Lampung Barat T.P 2015/2016. KONSELI Jurnal Bimbingan dan Konseling.

[28] Maslikan, M. (2018). Keefektifan Konseling Kelompok Realita Untuk Meningkatkan Pemahaman Identitas Diri Siswa Sekolah Menengah Pertama. Perspekt. Ilmu Pendidik. 